\title{
THE COMPARISON BETWEEN CONVENTIONAL, SHARIA, AND SOCIAL INSURANCE IN INDONESIA
}

\author{
${ }^{1}$ Bagas Heradhyaksa, ${ }^{2}$ Nurul Hikmah \\ ${ }^{1}$ Faculty of Sharia and Law, Walisongo State Islamic University, bagashera@walisongo.ac.id. \\ ${ }^{2}$ Ombudsman of Republic of Indonesia, nhikmah2011@gmail.com
}

\begin{abstract}
Insurance is a risk transfer agreement from the insured to the guarantor. Insurance is a financial institution whose development is quite rapid, both in the world and in Indonesia. Insurance in Indonesia has three forms, namely conventional, sharia, and social. Social Security Organizing Board in Indonesia named BPJS (Badan Penyelenggara Jaminan Sosial). Although all of them are the forms of insurance but has several differences. The fundamental differences are juridical differences and philosophical differences. The purpose of this study is to determine the juridical differences and philosophies of conventional, sharia, and social insurance. This research uses the juridical normative method. This method is used to analyze differences in conventional, sharia and social insurance by studying legal data related to the field. The results of this study found that the legal basis used in conventional, sharia, social insurance has differences. The philosophy of conventional insurance, sharia, and social also has differences. Therefore, although they are both in the form of insurance, conventional, sharia, and social insurance have significant differences respectively.
\end{abstract}

Keywords: Comparison; Insurance; Takaful; BPJS

\section{Introduction}

Based on research conducted by Hendrisman Rahim ${ }^{1}$, the insurance industry in Indonesia is still very dependent on economic growth. However, the national insurance industry is still able to contribute to economic development in Indonesia. Meanwhile, on the other hand, the prospects and projections of the development of the insurance industry in the future still provide hope for a good future, which is realized with several appropriate policy agendas.

The term conventional insurance refers to the transfer of risk from the insured to the guarantor. Through risk transfer, insurance can also be used to take advantage of collecting funds from the public by giving promises to provide benefits to those who want to avoid risk. ${ }^{2}$

The development of the takaful industry in Indonesia and at the global level is fairly rapid. along with that, the insurance function is increasing and includes various services in the financial system. The Indonesian Financial Services Authority has stated that the number of insurance companies in Indonesia in 2011 amounted to 43 companies while in 2015 there were $55 .{ }^{3}$ Sharia insurance company was first established in 1994 through Syarikat Takaful Indonesia Company.

1 Hendrisman Rahim, "Optimisme Pertumbuhan Asuransi Indonesia: Proyeksi Perkembangan Lima Tahun (20142018)," Jurnal Asuransi dan Manajemen Resiko 1, No.2 (2013): 1.

A. Junaidi Ganie.Hukum Asuransi Indonesia, (Jakarta: Sinar Grafika, 2011), 31.

3 Bagas Heradhyaksa and Ruzian Markom, "Jurisdiction of Sharia Supervisory Board in Indonesian Takaful Industry,” in IOP Conf. Ser.: Earth Environ. Sci. 175012177 (2018) 
Syarikat Takaful Indonesia Company has two subsidiaries, namely Asuransi Takaful Keluarga Company and Asuransi Takaful Umum Company. ${ }^{4}$

Countries with a Muslim majority population such as Indonesia, in general, have a relatively lower level of penetration and level of insurance density compared to other countries. This is due to religious beliefs that do not allow conventional insurance practices. In addition to overcoming these religious barriers, the nature of sharia insurance will have the potential to develop in Indonesia for the reason that the majority of the population is Muslim will tend to respect solutions that come from their own religion. ${ }^{5}$

Starting January 1, 2014, the Government of Indonesia has provided health insurance for all Indonesian people. The health insurance is organized by the Social Security Organizing Agency (BPJS). Health insurance is organized nationally with the principle of social insurance and the principle of justice with the aim of ensuring that participants receive health care and protection benefits to meet basic health needs. BPJS Health is a public legal entity that is organized under the President. BPJS also provides health insurance for all Indonesians, including foreigners who have worked for at least 6 months in Indonesia. ${ }^{6}$ Social insurance is specifically guaranteed by the state. This is based on Law Number 24 of 2011 concerning the Social Security Organizing Agency. The consequence of the enactment of this law is the transfer of functions of social security institutions. The authority over this function is transferred from PT. Askes and PT. Jamsostek to the Social Security Administrator. The purpose of the transition is to achieve universal coverage of insurance benefits that can cover all levels of society, including ordinary people. Now social insurance continues to grow along with the membership of the Social Security Administrator which is mandatory for the entire community.

The state of the art of this study is to determine the juridical differences and philosophies of conventional, sharia, and social insurance. The three types of that insurance also have special characteristics that differ from one another. One example is the nature of social insurance which is not based on agreements between the parties but is regulated by law as compulsory insurance. ${ }^{7}$

4 Novi Puspitasari, "Sejarah Dan Perkembangan Asuransi Islam Serta Perbedaannya Dengan Asuransi Konvensional," Jurnal Ekonomi Akuntansi Dan Manajemen 10, No. 2 (2015). ISSN 2459 - 9816. Accessed September 8, 2019. https://jurnal.unej.ac.id/index.php/JEAM/article/view/1202.

5 Herry Ramadhani, "Prospek Dan Tantangan Perkembangan Asuransi Syariah di Indonesia," Al-Tijary Jurnal Ekonomi dan Bisnis Islam 1, No.1 (2015): 64.

6 Widya L.H., Sudarsono H. Azhar K., "Health Reform in Indonesia towards Sustainable Development Growth (Case Study on BPJS Kesehatan, Health Insurance in Indonesia)," Review of Integrative Business and Economics Research 6, Issue 3 (2017):. 379.

7 Law Number 24 year 2011 about the Social Security Organizing Board verse 14. 
This is different from Islamic insurance and conventional insurance which bases the implementation of insurance with an agreement or contract. ${ }^{8}$

The next difference is the philosophical foundation of the implementation of Islamic insurance which is based on a sense of help and mutual protection from distress by referring to Islamic law. This is certainly different from the conventional insurance foundation and social insurance. The basis of the operational spirit of conventional insurance is oriented to the capitalist system which essentially plays in the collection of capital for personal or group interests. ${ }^{9}$ Meanwhile, this is also different from social insurance which is carried out on a nonprofit basis and is held to achieve the welfare of the community in general. Apart from the above differences, there are still many other differences between insurance concepts in Indonesia. ${ }^{10}$

\section{Method}

The philosophy of science distinguishes science from two points of view, namely positivistic views that produce empirical science and normative views that produce normative science. ${ }^{11}$ Both views are held by law. The method of approach used by researchers in writing this law is the normative juridical approach. A normative juridical approach is a study conducted with an emphasis on legal theories and legal rules relating to the problem under study.

The research specifications used in this study are analytical descriptive. Descriptive research is intended to provide accurate data about humans, circumstances, or other social symptoms. Descriptive research also aims to reinforce hypotheses in order to help in strengthening old theories or in developing new theories. ${ }^{12}$ The new theory seeks to describe the applicable laws and regulations associated with legal theories and the practice of implementing positive laws concerning conventional, sharia, and social insurance in Indonesia.

Descriptive method is a problem-solving procedure that is investigated by describing the state of the object of research at the present time based on the facts that appear. Furthermore, an analysis is carried out through the applicable regulations related to legal theories, opinions of

\footnotetext{
8 Abdullah Amrin, .Asuransi Syariah (Keberadaan dan Kelebihannya di Tengah Asuransi Konvensional, (Jakarta: Penerbit Elex Media Komputindo, 2006), 33.

9 AM. Hasan Ali, Asuransi dalam Perspektif Hukum Islam (Suatu Tinjauan Analisis Historis, Teoritis, \& Praktis), (Jakarta: Kencana, 2004), 55.

10 A. Abbas Salim, Dasar Dasar Asuransi (Principles of Insurance), (Bandung: Penerbit Tarsito, 1985), 84.

11 Philipus M Hadjon and Tatiek Sri Djatmiati, Argumentasi Hukum, (Jogjakarta: Gajah Mada University Press, 2005), 3.

12 Soerjono Soekanto, Pengantar Penelitian Hukum, (Jakarta: UI Press, 1984), 10.
} 
scholars, practitioners, and implementation practices related to the concept of sharia insurance, conventional insurance, and social insurance.

The legal data used in this study are only legal data relating to conventional, sharia, and social insurance. It is intended to prevent irregularities and obscurity in the discussion. The data that has been collected is analyzed to get clarity on the problem to be discussed. All data that has been collected is edited, processed, and arranged systematically and then presented in a descriptive form

\section{Result and Discussion}

\subsection{The Definition of Conventional Insurance}

One of the ways that someone can do to transfer the risk is by entering into a risk transfer agreement with another party. The agreement is referred to as an insurance agreement. ${ }^{13}$ Therefore, every time people talk about insurance, they will come to the thought of the statement that insurance is a way to reduce or avoid or avoid risk.

In Dutch, insurance is called "verzekering" which means coverage. In insurance involving two parties, namely one party that is able to bear is called as a guarantor, while the other party will get compensation for a loss, which he may suffer as a result of an event that originally could not be determined when it will occur. ${ }^{14}$

Black's Law Dictionary ${ }^{15}$ defines insurance as an agreement on which the insurer promises to do something of value to the insured if certain events occur. An agreement which is the basis for one party to take over a risk faced by another party in return for the payment of a premium.

Article 1 Number 1 of Law Number 40 year 2014 about Insurance provides an understanding of insurance, namely:

Insurance is an agreement between two parties, namely the insurance company and the policyholder, which is the basis for receiving premiums by the insurance company in return for: a) provide compensation for the insured or policyholder due to loss, damage, costs incurred, lost profits, or legal liability to third parties that may suffer the insured or policyholder due to an uncertain event; or b) provide payments based on the death of the insured or payments based on the life of the insured with benefits the amount of which has been determined and/or based on the results of fund management.

\footnotetext{
13 Sri Rejeki Hartono, Hukum Asuransi dan Perusahaan Asuransi, (Jakarta: Sinar Grafika, 2001), 14-15.

14 Wirjono Prodjodikoro, Hukum Asuransi di Indonesia, (Jakarta: Penerbit Intermasa, 1981), 1.

15 Henry Campbell Balck, Black's Law Dictionary, (West Group, 1999), 270.
} 
The term insurance also refers to the legal terms used in the legislation and insurance company. The term insurance comes from the word "insurance" which means coverage or protection of an object from the threat of harm that causes harm. If the word insurance is given an affirmation at the beginning and end of the word, then comes the legal term "insurance", which means all business relating to insurance. There are two types of businesses related to insurance, namely ${ }^{16}$ : a) Business in the field of insurance activities is called the insurance business. Companies that run insurance businesses are called insurance companies. b) Businesses in the field of supporting insurance business activities are called complementary insurance businesses. Companies that run insurance support businesses are called complementary insurance companies.

The definition of "insurance" always includes two types of business activities, namely the insurance companies and the complementary insurance companies. Insurance companies always include insurance companies and complementary insurance companies.

Based on the description, it can be concluded that insurance is a person's effort to delegate risk to other parties. Meanwhile, the party overflowed with risk will get a reward for the handover. The delegation then gives birth to an idea in the field of business where the delegation of risk can generate profits for business actors. Now the business in the insurance field continues to grow with a variety of types over the times.

\subsection{The Definition of Sharia Insurance}

Understanding sharia insurance, in general, is actually not much different from conventional insurance. Between the two, both conventional insurance and sharia insurance have in common. The equation is only functioning as a facilitator of the structural relationship between the premium payment participant (the insurer) and the recipient of the claim payment (the insured). In general, Islamic insurance or often termed takaful can be described as insurance whose operational principles are based on Islamic law by referring to the Qur'an and Sunnah. ${ }^{17}$

The term sharia insurance has several names namely takaful (Arabic), ta'min (Arabic), and Islamic insurance (English). The terms basically do not differ from one another which implies coverage or mutual bearing. But in practice, the most popular term used as another term for insurance and also the most widely used in several countries including Indonesia is the term

16 Abdulkadir Muhammad, Hukum Asuransi Indonesia (Bandung: Citra Aditya Bakti, 1999), 5.

17 H. A. Dzajuli dan Yadi Janwari, Lembaga-lembaga Perekonomian Umat (Sebuah Pengenalan), (Jakarta:Raja Grafindo Persada, 2002), 120. 
takaful. The term takaful was first used by Dar Al Mal Al Islami, an Islamic insurance company in Geneva that was founded in 1983.

The term takaful in Arabic comes from the basic word kafala-yakfulu-takăfala-yatakăfalutakăful which means mutual bearing or bearing together. The word takaful is not found in the Qur'an. However, there are a number of words that are as similar to the word takaful, as for example in QS Thaha (20): 40 "... That is adullukum 'ală man yakfuluhu ...." which means "... may I show you the person who will take care of it? ..."

Takaful in the sense of muamalah fiqh is social security among fellow Muslims. So that one with the other is willing to take risks. Willingness to bear the risk is essentially a form of help to help on the basis of kindness (tabarru') to ease the burden of suffering his brother who was stricken by disaster. ${ }^{18}$ Therefore, the idea of takaful insurance is related to the element of mutual risk among the insurance participants, where one participant is the guarantor of the other participant. The insurance company acts as a facilitator who is mutually responsible among the insurance participants. ${ }^{19}$

Meanwhile, according to fatwa No. 211/DSN-MUI/X/001 regarding General Sharia Insurance Guidelines, the understanding of Sharia insurance (ta'min, takaful, tadhamun) is an effort to protect and help each other among a number of people or parties through investments in the form of assets and or Tabarru funds' which provides a pattern of return to face certain risks through a contract (engagement) in accordance with sharia. ${ }^{20}$

Law Number 40 of 2014 concerning Insurance also provides its own understanding of sharia insurance. Based on this law, Sharia Insurance is a collection of agreements, consisting of agreements between sharia insurance companies and policyholders and agreements between policyholders, in the context of managing contributions based on sharia principles in order to help and protect one another.

Based on this explanation, it can be seen that Islamic insurance is insurance whose operations are based on Islamic law and include mutual protection efforts, please help, and bear the risk of each other. Then it can be concluded also that Islamic insurance is not an economic institution whose purpose is only looking for profits, but also has social value. The social value is an effort to help each other among the participants of Islamic insurance.

18 Zainuddin Ali, Hukum Asuransi Syariah.,Jakarta: Sinar Grafika, 2008), 4.

19 Rahmat Husein, Asuransi Takaful Selayang Pandang dalam Wawasan Islam dan Ekonomi (Jakarta:Lembaga Penerbit FE-UI, 1997), 234.

20 Burhanuddin S, Aspek Hukum Lembaga Keuangan Syariah (Yogyakarta: Graha Ilmu, 2010), 97. 


\subsection{The Definition of Social Insurance}

Social Insurance is designed to provide a minimum of protection against hazards that tend to procedure dependency problems for society. In general, what is guaranteed in social security is the social risk and is the responsibility of the community. Whereas the guaranteed life insurance is a personal risk. ${ }^{21}$

Organizing social security in accordance with the mandate of the Preamble to the 1945 Constitution of the Republic of Indonesia that the purpose of the state is to improve the welfare of the people. The Fourth Amendment to the 1945 Constitution of the Republic of Indonesia, emphasized the purpose of this goal, namely by developing a social security system for the welfare of all people.

National social security system is a state program that aims to provide certainty of protection and social welfare for all people as mandated in Article $28 \mathrm{H}$ verse (1), verse (2), and verse (3) and Article 34 verse (1) and verse (2) The 1945 Constitution of the Republic of Indonesia. In addition, in the Decree of the People's Consultative Assembly Number X / MPR / 2001, the President was assigned to form a national social security system in order to provide a more comprehensive and integrated social protection for the people.

Along with the enactment of Law Number 40 of 2004 concerning the National Social Security System, the Indonesian people already have a Social Security system for all the people of Indonesia. In order to realize the objectives of the national social security system, an organizing body in the form of a public legal entity needs to be formed based on the principles of mutual cooperation, non-profit, openness, prudence, accountability, portability, mandatory participation, trust funds, and the results of the management of Social Security Funds used entirely for the development of the program and for the maximum benefit of Participants. ${ }^{22}$

The National Social Security System is basically a state program aimed at providing certainty of protection and social welfare for all Indonesian people. Through this program, each resident is expected to be able to meet the basic needs of a decent life if things happen that can result in lost or reduced income. Either due to illness, accident, loss of work, entering old age, or retirement.

Along with the promulgation of Law Number 24 of 2011 concerning the Social Security Organizing Agency, the program mandated by the social security system is then organized by the Social Security Administrator. The implementation of the Social Security Administrator is

21 A. Abbas Salim, Dasar Dasar Asuransi (Principles of Insurance), (Bandung: Penerbit Tarsito, 1985), 83.

22 Explanation of Law Number 24 year 2011 about the Social Security Organizing Board verse 14 
carried out in order to achieve the objectives of the National Social Security System in accordance with the mandate of the Law.

The previous explanation illustrates that social security in the form of programs organized by the Social Security Administrator is part of the type of social insurance in general. It is the state's obligation to provide protection in the form of guarantees to its people. This is done in order to meet the aspects of welfare and decent living which is the right of every citizen.

\subsection{Philosophical Comparison}

The philosophical basis behind the emergence of conventional insurance is the idea that humans are filled with uncertainty about the future. In addition, that loss always threatens human life. On the basis of these thoughts, people with their minds and minds try to find ways to anticipate situations or risks that threaten them. The method adopted in order to anticipate a loss is by transferring it to another party

In the future, insurance becomes a human effort to take advantage through the collection of funds from the community. This is done by giving promises to provide benefits to those who want to avoid the threat of risk arising from uncertainty.

The philosophical basis of conventional insurance is different when compared with other philosophical grounds of insurance. For example, the philosophical basis of Islamic insurance which bases its activities on the teachings of Islam. Islam provides a complete set of rules for human life. This also includes issues regarding social relations such as economic activities and insurance. Islamic insurance activities, in particular, are based on the idea that there is a need to help one another, help, and bear the burden (takaful) between fellow human beings. Such is the rationale that forms the philosophical basis for Islamic insurance.

Social insurance has a philosophical basis, namely that the state has a duty to meet the welfare of the people. So that the state should provide social protection in order to achieve a decent life for each of its people. The form of social protection that the state can provide to its people can be in the form of social insurance. The implementation of social insurance in Indonesia is carried out in the form of social security in accordance with the mandate of the National Social Security System. The following is a comparative presentation on the philosophical basis of conventional, sharia and social insurance in tabular form. 
Table 1.

Comparison of Philosophical Basis

\begin{tabular}{|c|c|c|c|}
\hline & Conventional & Shariah & Social \\
\hline $\begin{array}{l}\text { Philosophical } \\
\text { Basis }\end{array}$ & $\begin{array}{l}\text { The human desire to } \\
\text { transfer the risk of loss } \\
\text { to another party. }\end{array}$ & $\begin{array}{l}\text { Islam is a way of life that } \\
\text { provides rules for all human } \\
\text { life, including insurance. } \\
\text { Sharia insurance is based on } \\
\text { a sense of help and bearing } \\
\text { one another's burdens }\end{array}$ & $\begin{array}{l}\text { The obligation for the state to } \\
\text { fulfill the people's welfare. } \\
\text { The state guarantees social } \\
\text { protection for its people so } \\
\text { that they can live a decent life. }\end{array}$ \\
\hline
\end{tabular}

Source: Author's data

Based on the description, the philosophical foundation of the three types of insurance mentioned above, then it can then be compared differences from each of the rationale underlying an insurance system. This illustrates that the philosophical foundation is a fundamental foundation that can provide an overview of an insurance system.

The philosophical basis underlying Islamic insurance is a noble foundation. This is based on the understanding that Islam is a way of life that regulates all aspects of human life, including matters of human relations. Sharia insurance is also based on the understanding that fellow Muslims are bound by brotherhood and the obligation to help one another and help one another.

This is different from conventional insurance which bases its activities on the aspect of delegating risk and seeking profit alone, and social insurance based on the idea that the state has an obligation to organize social security for its people. Through the above explanation, an understanding will emerge that the philosophical basis determines a system. That means, the better the base used, the better the system will be.

\subsection{Comparison of Juridical Basis}

The insurance system in Indonesia is governed by regulations issued by the government. This is because the insurance business is an institution that collects funds owned by the community, and must run its business based on the principles of sound and responsible business. $^{23}$ Therefore, every insurance system must comply with the regulations set by the government. Conventional insurance is based on several arrangements, namely: a) The Civil Code of Indonesia which contains arrangements regarding agreements in general and becomes a guideline in the implementation of insurance agreements; b) The Commercial Law Code of Indonesia is divided into general and special regulations. General arrangements are for all types

23 A. Junaedy Ganie, Hukum Asuransi Indonesia (Jakarta: Sinar Grafika, 2011), 52. 
of insurance. While arrangements are specifically intended, as is the case for fire insurance or agricultural insurance; c) Law Number 40 of 2014 concerning Insurance which is the latest law in the field of insurance, supersedes Law Number 2 of 1992 concerning Insurance Business which is more than 22 years old.

Sharia insurance also has the same legal basis as conventional insurance, which refers to the Insurance Act. The presence of the Insurance Act reinforces the position of sharia insurance in Indonesia. That's because the previous law was considered to be less accommodating of sharia insurance. ${ }^{24}$ Although there has been a formal legal basis governing Islamic insurance, Islamic insurance still bases its practice by referring to Islamic law and normative grounds. Article 1 Number 3 of the Insurance Law states that sharia insurance is carried out using sharia principles. Sharia principles are Islamic legal principles in insurance activities based on fatwas issued by institutions that have the authority to determine fatwas in the sharia field.

The Islamic legal basis for sharia insurance refers to the Qur'an, Sunnah, and Ijtihad. While the normative basis of Islamic insurance in the form of a fatwa issued by DSN MUI regarding Islamic insurance guidelines and other guidelines relating to Islamic insurance.

Social insurance also has its own juridical basis that underlies its operations in Indonesia. Social insurance in Indonesia is organized in the form of social security. The mandate regarding the implementation of social security contained in the 1945 Constitution of the Republic of Indonesia Article $28 \mathrm{H}$ verse (1), verse (2), and verse (3), and Article 34 verse (1) and (2). Meanwhile, social security is also specifically regulated in Law Number 40 of 2004 concerning the National Social Security System as well as in Law Number 24 of 2011 concerning the Social Security Organizing Board.

Arrangements regarding social security are specifically regulated as stated in the description above. This is in line with the participation of social security which is mandatory and intended for the welfare of all Indonesian people.

\footnotetext{
${ }^{24}$ AM. Hasan Ali, Asuransi dalam Perspektif Hukum Islam (Suatu Tinjauan Analisis Historis, Teoritis, \& Praktis), (Jakarta: Kencana, 2004), 154.
} 
Table 2.

Comparison of Juridical Basis

\begin{tabular}{|c|c|c|c|}
\hline & Conventional & Sharia & Social \\
\hline $\begin{array}{c}\text { Juridical } \\
\text { Basis }\end{array}$ & $\begin{array}{l}\text { 1) The Civil Code of } \\
\text { Indonesia } \\
\text { 2) The Commercial Law } \\
\text { Code of Indonesia } \\
\text { 3) Law Number } 40 \text { of } 2014 \\
\text { concerning Insurance }\end{array}$ & $\begin{array}{l}\text { 1) Law Number } 40 \text { of } 2014 \\
\text { concerning Insurance } \\
\text { 2) Indonesia Council of } \\
\text { Ulama }\end{array}$ & $\begin{array}{l}\text { 1) Indonesia Constitution } \\
\text { 2) Law Number } 40 \text { of } 2004 \\
\text { about the National Social } \\
\text { Security System } \\
\text { 3) Law Number } 24 \text { of } 2011 \\
\text { about the Social Security } \\
\text { Organizing Board. }\end{array}$ \\
\hline
\end{tabular}

Source: Author's Data

The diversity of the three types of insurance arrangements shows that the needs of the law in each type of insurance is different. Conventional insurance requires insurance laws that can accommodate insurance in Indonesia. The Insurance Act also forms the basis for the development of conventional insurance in the middle of the insurance industry. Meanwhile, although the existence of sharia insurance has been regulated in the Insurance Act, sharia insurance has its own needs because it bases its implementation also on its main sources namely Al Quran, Sunnah, and Ijtihad. In Indonesia, specific guidelines regarding the implementation of sharia insurance are accommodated by a fatwa issued by the Indonesian Council of Ulama. In addition, social insurance which is organized in the form of social security also has its own arrangements regulated in the Indonesian Constitution, the National Social Security System Act, and the Social Security Administrator Act.

\subsection{Comparison of Operational Concepts}

The concepts of operational insurance conventional, sharia, and social are different from each other. This is in accordance with the philosophical and juridical basis used by these three types of insurance. The basic difference between the three illustrates the differences in the guidelines used between one another. This makes a difference in the operational concept of each type of insurance.

As for proving this, the researcher made several sub-indicators used in the comparison of conventional, sharia, and social insurance operational concepts in Indonesia. These subindicators include: a) Insurance premium; b) Insurance agreement/contract; c) Investment funds; d) The elements of uncertainty, gambling, and interest.

The sub-indicators are expected to provide comparative results that represent the conventional, sharia, and social insurance operational concepts in Indonesia: 
a) Insurance Premium. Under the Insurance Law article 1 subsection 29, the definition of premium is an amount of money determined by an insurance company or reinsurance company and agreed by the policyholder to be paid based on an insurance agreement or reinsurance agreement. Premiums can also be interpreted as an amount of money determined based on statutory provisions that underlie the mandatory insurance program to obtain benefits.

The amount of the premium is determined from the results of the risk selection carried out by the underwriter or after the company has selected the risk at the request of the prospective insured. Thus the prospective insured will pay insurance premiums in accordance with the level of risk for their respective conditions. ${ }^{25}$

Determination of the rate is the most important thing in insurance to determine the amount of the premium. The ideal premium rate is a rate that can cover claims and various insurance costs and a portion of the company's revenue. Premiums on conventional insurance have elements that are different from other insurance. The premium consists of, namely ${ }^{26}: 1$ ) Mortality table, which is a list of death tables, is useful to find out the magnitude of the claims that are likely to arise due to loss of life. As well as predicting how long a person's age limit can live; 2) Interest receipts, namely in the context of setting rates. Interest calculation must be calculated therein; 3) Insurance costs consist of commission fees, non-official costs, advertisement fees, sale promotion, policy-making costs, administrative costs, maintenance costs, and other costs.

Premiums in conventional insurance are usually determined as a percentage of the amount insured. in this percentage, the risk assessment of the guarantor is reflected. Assessments or rewards from insurers regarding this risk may be different for each insurer, but still always controlled by the law of supply and demand. ${ }^{27}$

Meanwhile, Islamic insurance premiums paid to the insured consists of two elements or parts. These elements are savings and tabarru '. Funds originating from the tabarru element 'cannot be used as agent commissioning fees or travel fees for agents so that the participant's funds remain intact or cash worth at that time. If a participant resigns, the premium will be fully refunded, except for benevolent funds or tabarru funds. ${ }^{28}$

25 Abdullah Amrin, Asuransi Syariah (Keberadaan dan Kelebihannya di Tengah Asuransi Konvensional, (Jakarta: Penerbit Elex Media Komputindo, 2006), 108.

26 Zainuddin Ali, Hukum Asuransi Syariah., Jakarta: Sinar Grafika, 2008), 71.

27 Emmy Pangaribuan, Seri Hukum Dagang: Hukum Pertanggungan, (Yogyakarta: Seksi Hukum Dagang Fakultas Hukum Universitas Gadjah Mada, 1990), 41.

28 Abdullah AmrinAsuransi Syariah (Keberadaan dan Kelebihannya di Tengah Asuransi Konvensional, (Jakarta: Penerbit Elex Media Komputindo, 2006), 9. 
The premium elements mentioned above have differences with social insurance. Premiums in social insurance use a progressive system. This means that insurance money (compensation) in social insurance is not always proportional to the amount of premium paid by the participant (the insured). Then it can be concluded that the premium used is not emphasized on individual justice.

b) Insurance Agreement. Another specialty found in conventional insurance, sharia, and social lies in the agreement used. Conventional insurance uses agreements made between the company and its customers through agents or other representing parties. Furthermore, the guarantor gets insurance premiums in lieu of the promised sums of payment. Whereas the insured obtains the sum insured in the event of a disaster or event in lieu of the premiums paid. The agreement is included in the category of sale and purchase agreement.

This is different from the contract in sharia insurance which is commonly known to use the term tabarru 'which is based on giving and assistance from one party to another party. Tabarru contract 'is part of tabaddul haq (transfer of rights). Although basically the Tabarru contract 'is only one-way and is not accompanied by a reward, there is a basic principle in it that is the value of the gift based on the principle of helping by involving insurance companies as fund management institutions.

In addition, there are also commercial contracts. For example mudharabah, wadhi'ah, wakalah, and so on. ${ }^{29} \mathrm{~A}$ commercial contract is realized when the funds collected in the insurance company are invested in the form of a business that is projected to generate profits. The profits from the investment are shared according to the agreed portion. Conversely, if the investment loses, the loss is shared between the insurance participant and the company. ${ }^{30}$

Other differences regarding agreements or contracts of each type of insurance can also be seen in social insurance. The agreement that occurs in social insurance does not come from an agreement between the parties like the other two types of insurance described in the previous description. This is based on the law, not the agreement of the parties.

c) Investment Funds. There are differences in the placement of investment funds in conventional, sharia, and social insurance in Indonesia. For example, in conventional insurance, investments must be made on the type of investment that will benefit and have the liquidity that is in accordance with the obligations that must be met by the company. The benefits of

Zainuddin Ali, Hukum Asuransi Syariah. Jakarta: Sinar Grafika, 2008), 69.

30 AM. Hasan Ali, Asuransi dalam Perspektif Hukum Islam (Suatu Tinjauan Analisis Historis, Teoritis, \& Praktis), (Jakarta: Kencana, 2004), 141. 
conventional insurance can be determined in advance on the basis of the calculation of interest rates that have been set in advance. Whatever the risk results that occur from investment activities carried out, one party will still get results in accordance with the amount of interest that has been determined. ${ }^{31}$ This is different from investing in Islamic insurance. Islamic insurance invests funds only in activities that are in accordance with Islamic principles. While profits for loss insurance obtained from underwriting surpluses do not belong to the company.

While in social insurance, investments can be made through the authority of the Social Security Administrator by considering aspects of liquidity, solvency, caution, the security of funds, and adequate returns. Investments made can use Social Security Administrator assets or social security fund assets in accordance with statutory regulations. Social Security Administrator in carrying out its activities using the principle of non-profit or not in the context of seeking profit. The principle of non-profit is the principle of business management that prioritizes the use of the results of the development of funds to provide maximum benefits for all Participants. $^{32}$

d) Gambling, Uncertainty, and Interest. Interest in conventional insurance appears in determining the amount of the premium rate for the use of interest calculation techniques. In addition, the determination of the results of income made at the beginning of the number of interest rates that have been determined is fixed. Economically, determining the initial interest income can result in one party's profits and losses on the other party. ${ }^{33}$

Meanwhile, the operational system of sharia originating from the Quran and Al-Hadith, clearly avoids things that are forbidden by Islamic law, such as gambling, uncertainty, and interest. Sharia insurance managers separate the participant's fund account from the tabarru account, so there is no mixing of funds. Likewise, this mechanism does not become an element of interest, both in the practice of loss and life insurance by using Islamic instruments as a substitute for the interest system. Examples such as mudharabah, wadhi'ah, wakalah, and so on.

Meanwhile, to avoid elements of gambling, Islamic insurance applies a reversing period since the beginning of the contract. Each member of Islamic insurance is entitled to get cash value whenever needed for all funds that have been paid. This is except for the tabarru funds or virtues that have been intended and given to help other participants affected by the disaster. So that participants have clarity on the source, utilization, and results made by the company for the

\footnotetext{
31 Zainuddin Ali, Hukum Asuransi Syariah., Jakarta: Sinar Grafika, 2008), 10.

32 Law Number 24 of 2011 about the Social Security Organizing Board.

33 Abdullah Amrin, Asuransi Syariah (Keberadaan dan Kelebihannya di Tengah Asuransi Konvensional, (Jakarta: Penerbit Elex Media Komputindo, 2006), 53
} 
interests of both parties. In addition, regarding the payment of customer claims and profitsharing provided by companies sourced from Tabarru funds' and the results of investment activities carried out by the company with a mudharabah system or other systems that are justifiably justified. ${ }^{34}$

While in social insurance, the issue of interest, uncertainty, and gambling is still a matter of much public debate. However, based on a fatwa issued by Nadhlatul Ulama in Central Java, Indonesia Social Security Organizing Board membership is halal and does not contain interest or gambling. That is because the principle of Indonesia Social Security Organizing Board is to help and be non-profit. ${ }^{35}$

\section{Conclusion}

The comparison between conventional, sharia and social insurance is divided into three indicators. The first is comparison of philosophical basis which is the rationale for implementing an insurance system. The difference in the implementation of conventional insurance, sharia, and social one of them due to philosophical basic differences between the three types of insurance.

The philosophical basis of conventional insurance is thought about future uncertainty and the threat of loss to someone. This gave rise to the idea of risk transfer to other parties. Such risk transfer efforts are then used by the insurer to obtain profits.

The philosophical basis of Islamic insurance is the rules in Islamic teachings. The teachings of Islam are considered as the way of life that regulates all human life, including activities among humans. Sharia insurance is also based on the idea that there is an obligation to help one another help, help, alleviate, and bear the burden of fellow human beings who are in trouble or affected by the disaster. The philosophical basis of social insurance is based on the idea that the state is obliged to organize a decent life for its people. The philosophical basis determines an insurance system. The better a philosophical basis that underlies a system, the better the system will produce.

A formal legal basis comparison in the form of guidelines or rules for the creation of an insurance institution that operates in a healthy and orderly manner. Insurance institutions raise public funds so the implementation must be done carefully. The juridical basis of conventional

\footnotetext{
34 Abdullah Amrin, Asuransi Syariah (Keberadaan dan Kelebihannya di Tengah Asuransi Konvensional, (Jakarta: Penerbit Elex Media Komputindo, 2006), 52

35 Rofiuddin, "NU Ditanya Soal BPJS, Riba atau Bukan," Accessed September 8, 2019, http://nasional.tempo.co/read/news/2015/01/07/078633344/NU-Ditanya-Soal-BPJS-Riba-atau-Bukan.
} 
insurance consists of the Indonesian Civil Code, Indonesian Commercial Law, and Law Number 40 year 2014 about Insurance.

The legal basis for sharia insurance is Law Number 40 year 2014 about Insurance. However, the provisions regarding Islamic insurance in the Insurance Act are not yet complete enough to regulate Islamic insurance. Therefore, in the implementation of sharia insurance, many holds on the decision of the Indonesia Council of Ulama.

The legal basis for social insurance consists of the Indonesian Constitution, Law Number 40 year 2004 about the National Social Security System, and Law Number 24 year 2011 about Social Security Administrators. The juridical basis clarifies the position of conventional, sharia and social insurance with the Social Security Administrator in Indonesia. However, Islamic insurance has its own needs so that the main implementation guidelines are sourced from the Qur'an, Sunnah, and Ijtihad in the form of a decision of the Indonesia Council of Ulama.

Comparison of operational concepts of conventional, sharia, and social insurance have different concepts from each other. There are three indicators, namely insurance premium, insurance contract, investment funds, and the elements of gambling, uncertainty, and interest. Through the indicators above, it can be seen that each type of insurance has a different concept from one another.

\section{References}

Ali, A.M.H. Asuransi dalam Perspektif Hukum Islam (Suatu Tinjauan Analisis Historis, Teoritis, \& Praktis). Jakarta: Kencana, 2004.

Ali, Z. Hukum Asuransi Syariah. Jakarta: Sinar Grafika, 2008.

Amrin, A. Asuransi Syariah (Keberadaan dan Kelebihannya di Tengah Asuransi Konvensional, Jakarta: Penerbit Elex Media Komputindo, 2006.

Black, H.C. Black's Law Dictionary. USA: West Group, 1999.

Burhanuddin S. Aspek Hukum Lembaga Keuangan Syariah. Yogyakarta: Graha Ilmu, 2010.

Dzajuli, H.A. dan Y. Janwari. Lembaga-lembaga Perekonomian Umat (Sebuah Pengenalan). Jakarta: Raja Grafindo Persada, 2002.

Ganie, A.J. Hukum Asuransi Indonesia. Jakarta: Sinar Grafika, 2011.

Habibie, L. W., S. Hardjosoekarto, and A. Kasim. "Health Reform in Indonesia towards Sustainable Development Growth (Case Study on BPJS Kesehatan, Health Insurance in Indonesia)." Review of Integrative Business and Economics Research 6, Issue 3 (2017). 
Hadjon, P.M. and T. S. Djatmiati. Argumentasi Hukum. Jogjakarta: Gajah Mada University Press, 2005.

Hartono, S.R. Hukum Asuransi dan Perusahaan Asuransi. Jakarta: Sinar Grafika, 2001.

Heradhyaksa, B. and R. Markom. "Jurisdiction of Sharia Supervisory Board in Indonesian Takaful Industry." IOP Conf. Ser.: Earth Environ. Sci. 175012177 (2018)

Husein, R. Asuransi Takaful Selayang Pandang dalam Wawasan Islam dan Ekonomi. Jakarta: Lembaga Penerbit FE-UI, 1997.

Muhammad, A. Hukum Asuransi Indonesia. Bandung: Citra Aditya Bakti, 1999.

Pangaribuan, E. Seri Hukum Dagang: Hukum Pertanggungan. Yogyakarta: Seksi Hukum Dagang Fakultas Hukum Universitas Gadjah Mada, 1990.

Prodjodikoro, W. Hukum Asuransi di Indonesia, Jakarta: Penerbit Intermasa 1981.

Puspitasari, Novi. "Sejarah Dan Perkembangan Asuransi Islam Serta Perbedaannya Dengan Asuransi Konvensional." Jurnal Ekonomi Akuntansi dan Manajemen 10, No. 2 (2015). $\begin{array}{lllllll}\text { ISSN } & 2459 & - & 9816 . & \text { Accessed } & \text { September }\end{array}$ https://jurnal.unej.ac.id/index.php/JEAM/article/view/1202.

Rahim, Hendrisman. "Optimisme Pertumbuhan Asuransi Indonesia; Proyeksi Perkembangan Lima Tahun (2014-2018).” Jurnal Asuransi dan Manajemen Resiko 1, No.2 (2013).

Ramadhani, Herry. "Prospek Dan Tantangan Perkembangan Asuransi Syariah di Indonesia." AlTijary Jurnal Ekonomi dan Bisnis Islam 1, No. 1 (2015).

Rofiuddin. "NU Ditanya Soal BPJS, Riba atau Bukan." Accessed September 8, 2019. http://nasional.tempo.co/read/news/2015/01/07/078633344/NU-Ditanya-Soal-BPJS-Ribaatau-Bukan.

Salim, A.S. Dasar Dasar Asuransi. Bandung: Penerbit Tarsito, 1985.

Soekanto,S. Pengantar Penelitian Hukum. Jakarta: UI Press, 1984. 